\title{
Collagen Mutant Mouse Models Provide an Important Tool to Study Osteoarthritis
}

\author{
Brandon J Rose ${ }^{1}$, Robert E Seegmiller ${ }^{2}$, Laura C Bridgewater ${ }^{3}$ and David L Kooyman ${ }^{1 *}$ \\ ${ }^{1}$ Department of Physiology and Developmental Biology, Brigham Young University, 4005 LSB, Provo, USA \\ ${ }^{2}$ College of Dental Medicine, Roseman University of Health Sciences, South Jordan, USA \\ ${ }^{3}$ Department of Microbiology and Molecular Biology, Brigham Young University, 4007 LSB, Provo, USA
}

"Corresponding author: David L Kooyman, Department of Physiology and Developmental Biology, Brigham Young University, 4005 LSB, Provo, UT 84602, USA, Tel: 801-422-6399; Fax: 801-422-0004; E-mail: david_kooyman@byu.edu

Received date: June 28, 2016; Accepted date: July 29, 2016; Published date: August 08, 2016

Copyright: (c) 2016 Rose BJ, et al. This is an open-access article distributed under the terms of the Creative Commons Attribution License, which permits unrestricted use, distribution, and reproduction in any medium, provided the original author and source are credited.

\section{Collagen Mutant Mouse Models}

Mutations in the human type II (COL2A1) collagen gene appear to be the basis for many skeletal disorders such as spondyloepiphyseal dysplasia [1], achondrogenesis, Kniest, and Stickler syndrome [2]. Several of these conditions include early-onset osteoarthritis in addition to the chondrodysplasia phenotype [3]. Other collagen genes are also involved etiologically in the chondrodysplasias, e.g., an autosomal dominant form of Stickler syndrome, characterized by mild spondyloepiphyseal dysplasia (SED) and early-onset osteoarthritis, results from a mutation involving the COL11A2 gene that encodes the a2 (XI) chain of the quantitatively minor fibrillar type XI collagen [4]. Multiple epiphyseal dysplasia in humans involving flattening of the epiphyses, shortening of endochondral bones, and early-onset osteoarthritis has been linked to a mutation in type IX collagen [5], and mice made transgenic for $\alpha 1$ (IX) mutation have been shown to develop osteoarthritis and intervertebral disc degeneration prematurely [6]. The Disproportionate micromelia (Dmm) mouse has a mutation that causes lethal dwarfism in the homozygote and mild dwarfism in the heterozygote. This strain of mouse has a threenucleotide deletion in the C-propeptide region of the Col2al gene, a gene highly conserved with its human homologue, COL2A1 [7]. Both genes encode for type II collagen, the most abundant protein in hyaline cartilage [8]. As a result of the Col2al deletion, Dmm/+ mice have a decrease of proteoglycan production in the hyaline cartilage that typically yields early onset degradation and OA. We have previously reported OA-like changes in a mouse model that bears a mutation in the Col2al gene, similar to that found in humans, that behaves as a recessive mutation resulting in no obvious phenotype in the heterozygote [9]. The mouse mutation was named spondyloepiphesial dysplasia congenita (sedc) [10] because when homozygous it produces features that resemble the most common clinical phenotypes of SED congenita in humans [11]. Thus in both mouse and human it is known that collagen gene mutations that lead to a wide variety of disorders of the skeletal system can also lead to premature osteoarthritis.

While chondrodysplasia models of OA have been important in advancing our understanding of OA, the majority of OA cases in humans are not associated with any recognizable features of chondrodysplasia. This raises the question of whether the cartilage collagen genes play a significant role in the majority of human OA, or are only relevant in the minority of cases associated with chondrodysplasias. It has been shown that, in fact, at least two different heterozygous point mutations in the triple helical domain of the COL2A1 gene can cause degenerative joint disease in humans in the absence of other phenotypic abnormalities [12]. We have also shown that the heterozygous sedc mouse, although morphometrically normal, exhibits early onset OA [9]. This puzzle was solved, in part, when we demonstrated using electron microscopy that compared with controls, mutant articular cartilage displayed decreased fibril diameter concomitant with increases in size of the pericellular space, Mankin and OARSI scores, cartilage thickness, chondrocyte clustering, proteoglycan staining and horizontal fissuring [13]. We concluded that collagen in the mutant's articular cartilage (both heterozygote and homozygote) fails to provide the normal meshwork required for matrix integrity and overall cartilage stability.

However, one area that mouse chondrodysplasia models may have particular importance is $\mathrm{OA}$ associated with apoptosis [14]. The unfolded protein stress response (UPR) has been implicated in OA progression. We and others have reported that collagen mutant mouse strains Dmm, Cho and Sedc exhibit distended ER and Golgi, consistent with the mis-folded type II collagen being trapped in the ER rather than secreted to the extracellular matrix $[15,16]$. We have previously reported a 1.66 fold increase in BiP expression in $\mathrm{Dmm} /+$ newborn articular cartilage compared to wild type $(\mathrm{p}=0.01)$. We have also observed increased expression of caspase-3 signaling in the Sedc mouse model knee and TMJ sections in association with a substantial decrease in cellularity.

Chondrodysplasia mouse models are an important tool to study $\mathrm{OA}$, given that they can help elucidate key bio-molecular pathways associated with the hypo-cellularity that is characteristic of this debilitating disease.

\section{References}

1. Ala-Kokko L, Baldwin CT, Moskowitz RW, Prockop DJ (1990) Single base mutation in the type II procollagen gene (COL2A1) as a cause of primary osteoarthritis associated with a mild chondrodysplasia. Proc Natl Acad Sci U S A 87: 6565-6568.

2. Korkko J, Ritvaniemi P, Haataja L, Kaariainen H, Kivirikko KI, et al. (1993) Mutation in type II procollagen (COL2A1) that substitutes aspartate for glycine alpha 1-67 and that causes cataracts and retinal detachment: evidence for molecular heterogeneity in the Wagner syndrome and the Stickler syndrome (arthro-ophthalmopathy). American journal of human genetics 53: 55-61.

3. Bleasel JF, Holderbaum D, Mallock V, Haqqi TM, Williams HJ, et al. (1996) Hereditary osteoarthritis with mild spondyloepiphyseal dysplasia--are there "hot spots" on COL2A1? J Rheumatol 23: 1594-1598.

4. Ritvaniemi P, Körkkö J, Bonaventure J, Vikkula M, Hyland J, et al. (1995) Identification of COL2A1 gene mutations in patients with chondrodysplasias and familial osteoarthritis. Arthritis Rheum 38: 999-1004. 
Citation: Rose BJ, Seegmiller RE, Bridgewater LC, Kooyman DL (2016) Collagen Mutant Mouse Models Provide an Important Tool to Study

5. Briggs MD, Choi H, Warman ML, Loughlin JA, Wordsworth $\mathrm{P}$, et al (1994) Genetic mapping of a locus for multiple epiphyseal dysplasia (EDM2) to a region of chromosome 1 containing a type IX collagen gene. American journal of human genetics 55: 678-684.

6. Kimura T, Nakata K, Tsumaki N, Miyamoto S, Matsui Y, et al. (1996) Progressive degeneration of articular cartilage and intervertebral discs. An experimental study in transgenic mice bearing a type IX collagen mutation. International orthopaedics 20: 177-181.

7. Pace JM, Li Y, Seegmiller RE, Teuscher C, Taylor BA, et al. (1997) Disproportionate micromelia (Dmm) in mice caused by a mutation in the C-propeptide coding region of Col2a1. Dev Dyn 208: 25-33.

8. Bomsta BD, Bridgewater LC, Seegmiller RE (2006) Premature osteoarthritis in the Disproportionate micromelia (Dmm) mouse. Osteoarthritis Cartilage 14: 477-485.

9. Holt DW, Henderson ML, Stockdale CE, Farrell JT, Kooyman DL, et al. (2012) Osteoarthritis-like changes in the heterozygous sedc mouse associated with the HtrA1-Ddr2-Mmp-13 degradative pathway: a new model of osteoarthritis. Osteoarthritis Cartilage 20: 430-439.

10. Donahue LR, Chang B, Mohan S, Miyakoshi N, Wergedal JE, et al. (2003) A missense mutation in the mouse Col2al gene causes spondyloepiphyseal dysplasia congenita, hearing loss, and retinoschisis. J Bone Miner Res 18: 1612-1621.
11. Kawano O, Nakamura A, Morikawa S, Uetake K, Ishizu K, et al. (2015) Spondyloepiphyseal Dysplasia Congenita Caused by Double Heterozygous Mutations in COL2A1. American Journal of Medical Genetics Part A 167: 1578-1581.

12. Kannu P, Bateman JF, Randle S, Cowie S, du Sart D, et al. (2010) Premature arthritis is a distinct type II collagen phenotype. Arthritis Rheum 62: 1421-1430.

13. Macdonald DW, Squires RS, Avery SA, Adams J, Baker M, et al. (2013) Structural variations in articular cartilage matrix are associated with early-onset osteoarthritis in the spondyloepiphyseal dysplasia congenita (sedc) mouse. Int J Mol Sci 14: 16515-16531.

14. Liu-Bryan R, Terkeltaub $\mathrm{R}$ (2015) Emerging regulators of the inflammatory process in osteoarthritis. Nat Rev Rheumatol 11: 35-44.

15. Ricks ML, Farrell JT, Falk DJ, Holt DW, Rees M, et al. (2013) Osteoarthritis in temporomandibular joint of Col2al mutant mice. Arch Oral Biol 58: 1092-1099.

16. Chung HJ, Jensen DA, Gawron K, Steplewski A, Fertala A (2009) R992C (p.R1192C) Substitution in collagen II alters the structure of mutant molecules and induces the unfolded protein response. J Mol Biol 390: 306-318. 